(Continued from Vol. Ix., No. 169.)

Epilepsy. Aseassino epilettico. L. Lojacono i Salemi-Pace. Aroh. di psichiat., eto., Torino, 1891, xii., 498.

(Epilepsy, its treatment and psycho-forensic relations.) P. J. Kovalerski. Charkor, 1892, I. M. Varshachink, 239 p., 80.

The surgical treatment of. J. Price. J. Nerv. \& Ment. Dis., N. Y., 1892, xix., 396-407.

Traumatio epilepsy ; trephining; recovery; subsequent treatment by hypnotism; experiments with patient. A. H. Baines. Liverpool M.-Chir. J., 1892, xii., 233.239.

Epilepsija. P. J. Kovalevski. Aroh. psichiat., etc., Charkov, 1891, xviii., No. 3, 96-146; 1892, xix., No. 1, 41-66, No. 3, 88.116.

- Die Behandlung der Epilepsie mittelst Hypuotismus. M. Sihle. St Petersb. med. Wchnschr., 1891, n. F., viii., 404.

Epileptio colonies. C. T. Ewart. J. Ment. Sc., Lond., 1892, xxxviii., 212-222.

colony, Outline of a plan for an. F. Peterson. N. York M. J., 1892, lvi., 96.98.

Facial expressi n. Asymmetrical conditions met with in the faces of the insane, with some remarks on the dissolntion of expression. J. Turner. J. Ment. Sc., Loud., 1892, xxxviii., 18, 2 pl., 199.

Falsehood and insanity. Lüge und Geistesstörang. C. Moeli. Allg. Ztsohr. f. Psychiat., etc., Berl., 1891-2, xlviii., 257-300.

Food for the insane. Abstract of a lecture on the selection, preparation, and serving of food to the insane. H. A. Tomlinson. Hosp. Bull. Becond Minn. Hosp. Insane, Roohester, 1891-2, i., No. 3, 5-13.

Gall stones in the insane. C. F. Beadles. J. Ment. Sc., Lond., 1892, xxxviii., 382-397.

General paralysis. General paresis. R. M. Phelps. Hosp. Bull. Second Minn. Hosp. Insane, Roohester, 1891-2, i., No. 2, 3-11.

- On the initial phenomena of progressive paralysis. A paralygie pro. gressiva kezdeti tüneteiröl. E. E. Moravosik. Orvosi hetil., Budapest, 1892, cxxvi., 1; 15. Also, transl. (Abstr.) Pest. med.-chir. Presse, Budapest, 1892, xxviii., 243-246.

- (ttiology of). Some suggestions concerning the etiology of general paralysis. H. A. Tomlinson. J. Nerv. \& Ment. Dis., N. Y., 1891, xviii., 763-784

The diathesis of. G. R. Wilson. J. Ment. Sc., London., 1892, caxviii., 30-41.

Paresis, or general paralysis of the insane. G. L. Sinclair. Internat. Clin., Phila., 1891, ii., 290-302.

A study of nineteen cases of general paralysis of the insane. I. W. Blackburn. Rep. Gov. Hosp. Insane, Wash., 1891, 61-80, 6 pl.

- $A$ few remarks on general paresis. W. A. Macy. N. York M. J., 1891, liv., 663.

- Sur un cas de paralysie générale progressive à début trè précoce. J. M. Charcot et A. Dutil. Arch. de neurol., Par., 1892, xxiii., 145-156.

- Rapports de la paralyaie genérale précoce aveo l'aloooliame ancentral. Combemalo. Bull, med du nord., Lille, 1891, xxx., 646-552. 
General paralyais. Paralysie générale chez l'adolescent. Meroredi mód., Par., 1892, iii., 61-63.

- Morbid ohanges of liver in. Lésions du foie dans la paral ysio générale ; du foie vaso-paralytique. M. Klippel. Gaz. hebd. de méd., Par., 1892, 2 8., zxix., 17-20.

- De quelques formes isolites de la paralysie générale. B. B. For. Ann. de psychiat. et d'hypnol., Par., 1891, n.8., 337-340.

- and syphilis. Report of a case exhibiting the symptoms of general paralysis, but in which the post-mortem disclosed syphilitio brain disease. Elizabeth C. Mallison. Hosp. Bull. Second Minn. Hosp. Insane, Rochester, 1891-2, i., No. 3, 22-26.

- and syphilis. The relationship between general paralysis of the insane and syphilis. D. W. Jacobson. J. Ment. So., Lond , 1892, xxxiii., 175.185.

- (Progressive paralysis of the insane, combined with syphilis, and its treatmeut.) I. J. Platonoff. Arch. psichiat., etc., Charkov, 1892, xix., 1-21.

- La paralisi progressiva nell' Italia meridionale, R. Rosoioli. Manicomio mod., Nocera, 1891, vii., 33.74.

- Contribution à l'étude de la remisaion dans la paralysie générale. Guillemin. Ann. méd.-psych., Par., 1891, 7 8., xiv., 370-376.

- Zur Charakteristik der reflectorischen Pupillenstarre bei progressiver Parulyse. E. Redliob. Neurol. Centralbl., Leipz., 1892, xi., 307-312.

- Contributo all' anatomia patologica ed alla patogenesi della paralisi prngressiva. T. Brazzola. Arch. ital. per le mal. nerv., Milano, 1891, xxviii., 195-216.

Contribution à l'étude de l'anatomie pathologique de la paralysie générale. J. Luys. Ann. de paychiat. et d'hypnol., Par., 1891, n.8., 321.325.

- Sclérose en plaques et paralysie géuérale. Charcot. Semaine méd., Par., 1892, xii., 29.

- Le alterazioni dei nervi periferici nella paralisi generale progressiva in rapporto con $i$ loro nuclei centrali di origine. R. Colella. Ann. di neurol, Torino, 1891, n.8., ix., 115.200, 2 pl.

Pseudo-paralyrie générale d'origine alcoolique. Villard. Marseille mód., 1x!12, xxix., 117-133.

Genius and insanity. A. MacDonald. J. Ment. Sc., Lond., 1892, xxxviii., 186-195.

Gold and sodium chloride in general paralysis. Dn chlorure dor et de sodium dans la paralysie générale progressive. Bonila. Ann. med.psych., Par., 1892, 7 s., xv., $80,280$.

Grandeur, ideas of. Des idées de grandenr chez les persécutés. J. Christian. Arch. de neurol., Par., 1891, xxii., 325 ; 1892, xxiii., 35.

Eallucinations. Beitrăge zar Lehre von den Hallucinationen. Pick. Neurol., Centralbl., Leipz., 1892, xi., 329-337.

Zur Theorie der Hallucinationen. Tigges. Allg. Ztschr. f. Psychiat. etc., Berl., 1891-2, xlviii., 309, 386.

La base sensoris delle allucinazioni ; contributo clinico allo studio del disturbi sensoriali. 8. Tonnini. Rassegna clin. o statist. d. Villa di Balute di Palermo, 1891, j., fasc. 2, 3-29.

Hallncinations unilatórales chez une femme ayant une lésion circonsarite du cerveau. F. Toulouse. Gaz. d. hôp., Par., 1898, lxv., 594-597. 
Hallucinations in melancholia. Sur les hallucinations, et en particulier les hallucinations verbales psycho-motrices, dans la mélancolie. Arch. do neurol., Par., 1892, xxiii., 201, 386.

Hallucinatory inganity. Hallucinatorische Verrücktheit; motivirtes Gutachten Meissner. Vrtljschr. f. gerichtl. Med., Berl., 1892, 3 F., iii., 306-323.

Hereditary degenerates. Hén:éditaires dégénérés. Magnan. Arch. de neurol., $\mathrm{Par}_{4}$ 1892, xxiii., 304.323.

Homicide. Note sar un aliéné homicide. Camuset. Ibid., 157 ; 370.

Hygiene and psychological medicine. Hygieine und Psychiatrie. F. Kretzschmar. Gesundheit, Frankf. a M., 1892, xvii., 177, 196.

Hyoscine hydrochlorate. Valore terapentico dell' idroclorato d'ioscina nelle malattio mentali. G. Sanna-Salaris. Ann. di Freniat., etc., Torino, 1891-2, iii., 30-71.

- Hyoscin als Sedativum bei chronisch-geisteskranken Frauen. Näoke. Allg. Ztschr. f. Psychiat., etc., Berl., 1891-2, xlviii., 301-308.

Hypnotics. Sull' azione ipnotica del tetronale, nelle malattio mentali in comparazione con quella del sulfonale. L. Lojncono. Rassegna clin. e statist. d. Villa di Salute di Palermo, 1891, i., fasc. 2, 39-47.

- Sui nuovi ipnotici uralio; uretano cloralico; somnale; chloralforma. mide; ipnale; idrato damilene; metilal. B. Ciullini e C. Raimondi. Gaz. med. lomb., Milano, 1892, ii., 71, 81, 91, 102.

Hypnotism. F. R. Cruise. Tr. Roy. Acad. M. Ireland, Dubl., 1890-1, ix., 143-164.

R. Arthur. Australas. M. Gaz., Sỵdney, 1891.2, xi, 6i-71.

Should we give hypnotism a trial ? G. C. Kingsbury. Tr. Roy. Acad., M. Ireland, Dubl., 1890-1, ix., 165-180.

in lunatic asylums. Ceber die therapeutische Verwerthung der Hypnose in Irrenanstalten. O. Binswanger. Therap. Monatsh., Berl., 1892, vi., $105,163$.

- and crime. Hypnotisme et criminalité. J. Liégeois. Rev. phil., Par., 1892, xxxiii., 233-272.

The latest phases of. A. Vores. Australas. M. Gaz., Sydney, 1891-2, xi., 63-66.

and saggestion. R. Arthur. Indian M. Gaz., Calcutta, 1892, xxvii., 40,68 .

- and suggestion. Kaleidoskopische Studie über Hypnotismus und Suggestion. Otto von Berlin. Freiburg i. B., 1892, F. E. Fehsenfeld, 73 p., 120.

, suggestion and psychotherapy. Neue Studien über Hypnotismus, Suggestion und Peycotherapie. H. Bernheim. Uebersetzt von Sigm. Frend. Leipz. und Wien, 1892, F. Denticke, 392 p., 80.

Hysteria. De la nature de l'hystérie. Cousot. Bull. Soc. de méd. ment. de Belg., Gand et Leipz., 1892, 17.27.

Traitement de l'hystérie. P. Blocq. Gaz. d. hôp., Par., 1892, lxv., 561-567.

Hystero-catalepsy. An extreme case of ; trances lasting 58, 30, 24, and 12 bours; insanity; recovery. A. T. Sloan. Edin. M. J., 1891-2, xxxvii., 824.833.

Idiocy and imbecility. Der Idiot und der Imbecile; eine prychologische Studie. Ins Deutsche übersetzt von Paul Brie; mit einem Vorwort von C. Pelman. Paul Sollier. Hamb. and Leípz., 1891, L. Voss, 238 p., 12 pl., 80. 
Idiocy and imbecility. K. patholngischeskoi anatomii idiotisma. N. M. Popoff. Warshava, 1891, 31 p., 2 pl., 80.

and myrodema. Idiotie areo cachexie pachydermique (idiotie myroe. démateuse). Consot. Bull. Soo. de méd. ment. de Belg., Gand et Leipz., 1891, 4:1-427, 2 phot.

- Vision in. La vision chez les idiots et les imbéciles. A. Marie et J. Bonnet. Par., 1892, O. Doin, 144 p., 2 pl., 80.

A clinical study of the ocular symptoms found in the so-called Mongolian type of idiocy. C. A. Oliver. Tr. Am. Ophth. Soc., Hartford, 1891, vi., pt. i., 140-148.

Imbecility (Description of brain). Description du cerveau d'une femme inbécile. J. Luys. Ann. de psychiat. et d'hypnol., Par., 1892, n. 8., ii., 83.

- Imbecillität ; Epilepsie ? Kindesmord. R. von Krafft-Kbing. Friedreich's Bl. f. gerichtl. Med., Nürnb., 1892, xliii., 19-27. Also Wien. med. Bl., 1892, xv., 101-103.

Impulsive insanity. W. H. H. Russell. Med. Age, Detroit, 1892, x., 1-12.

Jnfluenza and neurosis. G. H. Savage. J. Ment. Sc., Lond., 1892, axxviii., $360-364$.

among the insane. R. M. Phelps. Northwest. Lancet, St. Paul, 1892, xii., 120.

- and cerebral disease. Two fatal cases of cerebral disease (one of confusional insanity, the other of doubtful nature) following grippe. $M$. Prince. Boston M. and S. J., 1892, cxxvi., 229-231.

Mental affections after. J. Althaus. Am. J. M. Sc., Phila., 1892, n. s. ciii., $361-381$.

The epidemic inflammatory neurosis; or, neurotio influenza. C. H. Hughes. Alien ist and Neurol., St. Louis, 1892, xiii., 297-312.

The nervous and mental phenomena and the sequelm of influenzs. C. K. Mills. North Car. M. J., Wilmington, 1892, vxix., 77.94.

La grippe de 1891.92 dans ses rapports avec l'aliénation mentale et les suicides. Reynand. Loire méd., St. Etienne, 1892, xi., 85.94, 4 diag.

- Sixteen cases of psychoses observed after. Meddelanden om psychoser efter influensa. H. Eurén. Upsala Läkeref. Förh., 1891-2, xxvii., 69.86 .

- in the insane asylum of Aarhus. Influenza-epidemien 1891-92 pas. Aarhus Sindssygeanstalt. C. Geill. Hosp.-Tid., Kjbenh., 1892, 3 R., X., $565,589,613$.

Insane (The) in Egypt. F. Peterson. Med. Rec., N. Y., 1892, xli., 573.

Insanity and its treatment. Lectures on the treatment, medical and legal, of insane patients. G. Fielding Blandford. 4 ed., Edinb., 1892, Oliver and Boyd, 516 p., 120.

Manuel pratique de médicine mentale; avec une préface par Benjamin Ball. E. Régis. 2 éd., entièrement revue et corrigée. Par., 1892, 0. Doin, 761 p., 120.

- Lehrbuch der Peychiatrie für Studirende und Aerzte. Theodor Kirchhoff. Leipz. und Wien, 1892, F. Deuticke, 572 p., 17 pl., 80.

pathology and therapy. Pathologie und Therapie der psychischen Kranbheiten für Aertze und Studirende. Wilhelm Griesinger. 5 Aufl. gänzlich umgearbeitet und erweitert von Willibald Levinstein-Schlogel. Berl., 1892, A. Hirschwald, 1130 p., 80. 
Insanity and its treatment. Insanity. B. Bramwell. In his Atlas of Clin. Med., fol., Edinb., 1891-2, i., 180-182, 4 pl.

Insanity. E. D. Fisher. Internat. Olin., Phila., 1892, ir., 21 5-223.

The origin of insanity. R. M. Bucke. Canad. Pract., Toronto, 1892, xvii., 219-224.

(Canses of diseases of the mind.) A. F. Erlitzki. St. Petersb., 1892, K. L. Bioker, 34 p., 2 tab., 80.

- The possibility of cure of insanity. C. G. Chaddock. Am. Lancet, Detroit, 1892, n. 8., xvi., 121-127.

- Cases of insanity in general practice. A. H. Newth. J. Ment. Sc., Lond., 1892, xxxviii., 80, 238.

The social and medical aspects of. John Punton. Kansas City, Mo., 1891,8 p., 80.

- (evidences of), The Supreme Court of Michigan on the. J. El. Fimerson. $\Delta \mathrm{m}$. Lancet, Detroit, 1892, n. 8., xvi., 161.163.

- Concerning the kinsmen and friends of insane patients. F. A. IHlkins. Edinb. M. J., 1891.2, xxxvii., 834-840.

- from nutritive disturbance. Aliénation mentale par les troubles de la nutrition; preuves expérimentales de l'existence de ce genre d' aliéartion. Mairet et Bosc. Ann. Méd.-psych., Par., 1892, 7 s., xv., 17-32.

(senile). Deux cas de folie sénile areo guérison. L. Daguillon. France méd., Par., 1892, xxxix., 65-68.

traumatic. Ueber zwei Fälle von tranmatischer Psychose. Heinrich Pust. Berl., 1892, W. Röwer, 30 p., 80.

Des obsessions en pathologie mentale. B. Ball. Ann. de psychiat. et d'hypnol., Par., 1892, n. s., ii., 1-15.

Manuale delle malattie mentali, esposto secondo il programma, nnversitario; parte speciale. Domenico Janni. Napoli, 1891, D. Cesareo, 117 p., 80.

Etude sur quelques symptômes des délires systématiśs et sur leur valeur. A Marie. Par., 1892, H. Jouve, 143 p., 80.

Les maladies de l'esprit. P. Max-Simon. Par., 1891, J. B. Baillière et fils, 319 p., 120.

Des folies diathésiques. H. Mabille et E. Lallemant. Par., 1891, G. Masson, 159 p., 40.

Divagazioni scientifiche. Note di un alienista. Ernesto Bonvecchiato. Torino, 1892, Fratelli Boca, 219 p., 1 phot., 80.

Report of a case of transitory frenzy. T. Diller. Alienist and Neurol., St. Louix, 1892, xiii., 339-342.

Le délire chronique à l'évolution systématique. Magnan et P. Sérienx. Par., 1892, Gauthier-Villars, 184 p., 120.

Entmündigungegutachten über einen Kranken mit hereditärem Irresein.

0. Dorublüth. Vrtljschr. f. gerichtl. Med., Berl., 1892, 3 F., iii., 32 1-339. Geistesstörungen in der Schule; ein Vortrag nebst 13 Krankenbildern. Christian Afer. Wiesbaden, 1891, l. F. Bergmann, 50 p., 80.

- Un cas de folie sans délire. E. Marandon de Montyel. Ann. méd.psych., Par., 1892, 7 8., x7., 384-399.

Insomnia, The treatment of. J. Collins. J. Nerv. and Ment. Dis., N. Y., 1892, xix., 685-641. 
Intellectual disturbances in some acute forms of insanity, and their final rela tion to anæmia. I. I. Netschai. Med. Obozr., Mosk., 1892, nxхvii., 401-422.

Jealougy (delusions) in man. Teber Eifersnchtswahn beim Manne. Jahrb. $f$. Paychiat., Leipz, n. Wien, 1891-2, x., 212-231.

Katatonia or insanity? Die Frage der Katatonie oder des Irreseins mit Spannung. Albert Bebr. Riga, 1891, W. P. Hiscker, 60 p., 80.

- Observations on katatonia. E. Goodall. J. Ment. Sc., Lond., 1892, zxoviii., 227-233.

— Case of so-called katatonia. R. P. Smith. Ibid., 403-407.

Ein classischer Fall Kahlbaum'soher Kalatonie. N. Ostermayer. Allg. Ztschr. t. Psychiat., etc., Berl., 1891-2, xlviii., 358-367.

[Katatonic insanity, Study on.] N. S. Scheshmintzeff. Russk. Med., St. Petersb., 1891, xvi., 743, 757.

Kidner disease and insanity. G. T. Tuttle. Am. J. Insan., Utica, N. Y., 1891-2, xlviii., 458-469.

Knee-jerk. On certain peculiarities of the knee-jerk in sleep in a case of terminal dementia. W. Noyes. Am. J. Psychol., Worcester, 1891-2, iv., 343-361, 2 charts.

Language as a test of mental capacity. H. Hale. J. Anthrop. Inst. Lond., $1891-2$, zxi., 413-455.

Legislation in the British Isles. De la légis]ation sur les aliénés dans les îles britanniques. Par., 1892, G. Steinheil, 136 p., 80.

- The Local Government Act of 1888 ; its probable action on the treatment of insanity in England. J. A. Campbell. J. Ment. So., Lond., 1892, xxxviii., 45-50.

Lunacy legislation in Italy. Brit. M. J., Lond., 1892, i., 624.

- Projet de loi portant révision de la législation sur les aliénés. Création de sociétés de patronage pour les aliénés sortant des asiles. Par., 1891, Melum, 200 p., 40.

- Le prijet de révision de la loi sar les aliénés à la Chambre des députés; rapport de M. Ernest Lafont. A. Giraud. Ann. méd -psych., Par., 1892, 7 s., xv., 337-354.

- Le projet de loi sur les aliénés du Conseil supérieur de l'assistance publique ; examen critique sommaire. S. Garnier. Ibid., 408-423.

- Le projet de révision de la loi sur les aliénés au Conseil supérieur de l'assistance publique. A. Giraud. Ibid., 5-16.

- Il progetto di legge Nicotera sugli alienati e sui manicomi. Antigono Raggi. Voghera, 1892, Gatti, 31 p., 80.

and inkanity. Die Unvollkommenheit der hentigen Psychiatrie und die Mangelhaftigkeit der deutschen Irrengesetzgebung mit Entwurf einer neuen Irrenprocessordnung; ein Wort zur Irrenfrage an Laien, Aerzte, nud Juristen. F. Kretzschmar. Leipz., 1891, R. Uhlig, 100 p., 80.

Lethargy, Case of. A. Robinsor. Am. J. Insan., Utica, N. Y., 1891-2, xlviii., 505-507.

Liberty, Instinct of. L'istinto di libertà nei pazzi. G. B. Verga. Arch. ital. per le mal. nerv., Milano, 1891, xxviii., 252.266.

Lunacy in Norway, 1891. W. Habgood. J. Ment. Sc., Lond., 1892, xxxviii., 41-45. 
With Illustrations, Two Vols. 8vo, 428.

\section{A DICTIONARY}

or

\section{PSYCHOLOGICAL MEDICINE}

GIVING THE DEFINITION, ETYMOLOGY AND SYNONYMS OF THE TERMS USED IN MEDICAL PSYCHOLOGY

AND THE

Law of Lunacy in Great Britain and Ireland.

IDITED BY

D. HACK TUKE, M.D., LL.D.,

Examiner in Mental Physiology in the University of London; Lecturer on Psychological Medicine at the Charing Oross Hospital Medical School; co-Editor of "The Journal of Mental Bcience."

ABSISTED BY NEARLY ONE HONDRED AND THIRTY CONTRIBUTORS.

"Fach contributor appears the master of his subject. In some ceses it maj be said that no other man, sare the actual contributor, possesses suficient knowledge or opportunity to hare written 80 complete and exhanstive a description of the subject treated."-Edinburgh Medical Journal, Oot., 1892.

“Thees substantial and neatly printed volumes are a comprehensive resume of the literature of alienism and a weloome addition to the library of the mental specislist. They owe their existence to the industry and energy of one who has already excelled in the preparation of works covering many branches of the subject. . . . Taken as a whole, the "Dictionery of Paychological Medicine" more than fulfils the high expectations which were formed by those who knew of the plans of its acoomplished anthor."-Johns Hopkins Hospital Bulletin, Bept., 1892.

"It is vastly more than a Dictionary. It is an elaborate and complete Encyclopedia of Poychological Medicine; in fact, a small library in itself on that subject. The high expectations which Dr. Tuke's work in this field had raised are more than fulfilled. . . . It will be found to be a moet useful reference hand-book for the alienist and student of Psychological Medicine. The general physician also cannot fail to find the book exceedingly useful in special cases." Boston Medical and Surgical Journal, Oct. 6th, 1892.

" Si nous avions un regret a exprimer, c'est qu'une cuvre de ce genre n'ait pas vu le jour en France plulot qu'en Angleterre. Mais la science est de tous les pays; elle appartient a tout le monde, ot co qui est bien certain, c'est que le Dr. Hack Tuke, en produisant le dictionnaire de módicinø mentale, aura rendu a la science módico-psychiatrique un signalé service. Ce dictionnaire, qui est tout a fait au courant de la science, peut tenir lieu des meilleurs traités, en meme tempe qu'il permit de ce renseigner aisément et avec promptitude sur n'importe quelle particularit6 nosologique." - Anrales Medico-Psychologiques, Jan., 1893.

"Ioe 6diteurs, MM. Ohurchill, méritent a leur tour nos plus sincères félicitations, non seulement pour avoir facilite la tache de l'entreprise mais encore en raison du soin particulier qu'ils ont voué au travail typographique." -Bulletin de la société de Medicine Mentale de Belgique.

“. . . The learned editor has chosen for his staff the most distinguished contributors and investigator, so that those who consult the dictionary will find under any of its multifarious headings the latest and best information. . . . Dr. Hack Tuke has enjoyed a wide reputation hitherto; but this most excellent treatise, for it is that rather than a dictionary, the fruit of much labour and meditation, will still further advance his fame."-Law Journal.

"Dr. Hack Tuke has just brought to a successful issue a great enterprise, which does the higheat credit to Fnglish medical and peychological science."-Brain.

London : J. \& 4. CHURCHILL, 11, New Burlington Btreot. 
Just Published. 8vo. Price 21s.

Psyehology, Deseriptive and Explanatory :

$\triangle$ Treatise of the Phenomena, Laws, and Development of Human Mental Life. BY GEORGE TRUMBOLL LADD,

Professor of Philosophy in Yale University.

London: LONGMANS, GREEN, \& CO.

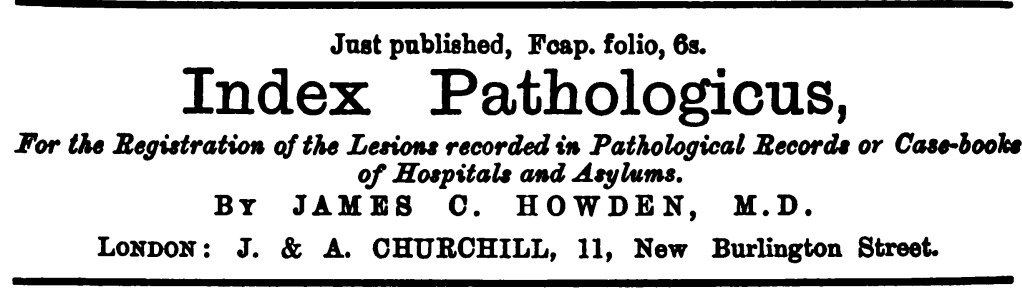

In preparation.

Mental Physiology,

ESPECIALLY IN ITS RELATIONS TO MENTAL DISORDERS.

BY THEO. B. HYSLOP, M.D., Assistant Physician, Bethlem Royal Hospital. LONDON: J. \& A. CHURCHILL, 11, New Burlington Street.

General Index to Journal of Mental Seience. 7 HE SECOND SERIES is now ready, extending from the 25th 1 to the 38th Vols. (inclusive), price 5s.

BY HENRY RAYNER, M.D.

LONDON : J. \& A. CHURCHILL, 11, New Burlington Street.

\section{In the Press. \\ A Practical Manual of Mental Medicine.}

By E. REGIS, M.D., Bonscat-Bordesnx, France,

Formerly Chief of Clinique of Mental Diseases at the Faculty of Medioine of Parie.

Second Edition, thoroughly revised. Translated by Dr. H. M. BAMmistze, Chicago, Ill., with a preface to American translation by the Author.

- Utica State Hospital Press, Utica, N.Y., U.S.A. Price 8s.

BULLETIN DE LA SOCIÉTÉ DE MÉDICINE MENTALE DE BELGIQUE.

Quarterly Subscription, 10 francs.-Apply to DR. JULFS MORFL, MGdeoin en Chef de l'Hospice Guislain, Ghent.

\section{The Asclepiad :}

A Book of Original Research and Observation in the Science, Art, and Literature of Medicine, Preventive and Curative. Price 2s. 6d.

BY SIR B. W. RICHARDSON, M.D., F.R.8.

Pablighed Quarterly by

Loxexuss, Grims \& Co., Paternonter Bor, London. 
CONTENTS OF No. 168.-JANUARY, 1894.

PART I,-ORIGINAL ARTICLES.

T. B. Clonston, M.D.-The Mental Symptoms of alyxoedems and the Effect on them of the Thyroid Treutment.

W. F. Farquharson, M.B.-On Melnncholin : An Anulyats of 730 Consecutive Cuses. Burgeon-Captaln J. H. TnII Walsh, I, M.8.-Hewp Drags and Insuntty.

Minical Notes and Cases.-Drvilopmental General Paralyeis; by Jasra Mridoreacasa. M.D.A Case for Jingnosis; by neotsalb A. Nour, M.B.

Oocesional Notes of the Quarter.-Sir Antrew Clurk, Burt.-The Disne of Inquisitions under the New Lunney Acts, $\rightarrow$ Forensie Hypnntisn. - Tlio Panisument of Hinbitunt Criminaln.-



PART II.-REVIEWS.

Thirty-Afth Annual Repart of the General Board of Commissioners in Innacy for Scotiand,-Fortyeecond Report of the Inspectars of Lannt:

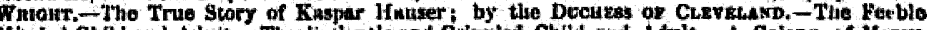
Miniled Chal and Aduit,-The Eplleptic and Crippled Chitd and Adult-A Colony of Mercy



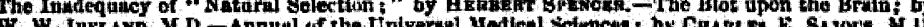



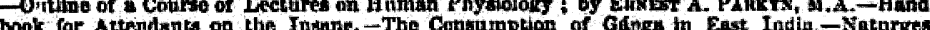

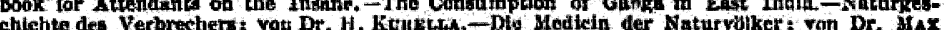
chichte des Verorechers: votr Drt. H. Kciizhia, - Dho Medein der Naturviker; ron Dr. MAX



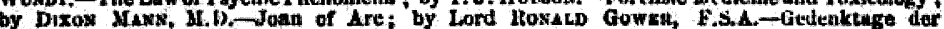

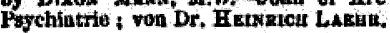

PARTIII.-PSYCHOLOGICAL RETROSPECT.

1. Engliah Retroepeet (Asyinm Reports).

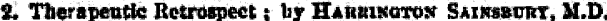

3. American Retronpect; by Furreubn Bxukn, M.D.

PART IV.-NOTES AND NEWS.

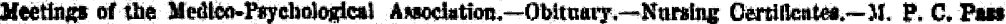
List.-Dute of next Quarterly Meeting.-Appointauuts, ote.

CONTENTS OF No. 169.-APRIL, 1894.

PART I.-ORIGINAL ARTICLES.

Alfred W. Campbell, M.D. - A Contribution to the Xorbed Antomy and Patholegy of the Neuro-yinseniar Changes in General Paralysis of thie Insane.

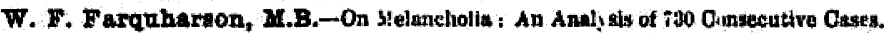

A. R. Urewhart, M.D.-Current Opinion on Medleo-Paychologicul Questlons in Germuny.

I. B. Eanborn, Feq.-I American Insanity Incrensiog?

D. Heok Tuke, F.R.C.P.-Alleged Increase of Insanity.

Cunical Notes and Cases.-The Insanity of the Clumateric Peritod; by Drs. E. Goobste end M. Carie.

Occasional Notes of the Quarter.-Census of Eneland and Wales, 1891.-The Lewlishm Workhoune Inquiry.-Amertcan superiatendents und the New Yurk Lunacy Counmisaion.-

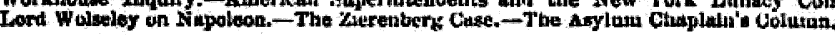

PART II.-REVIEWS.



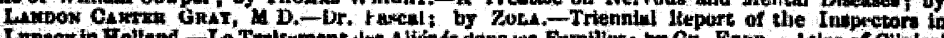

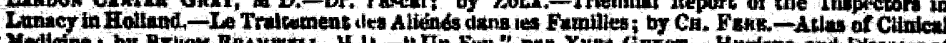

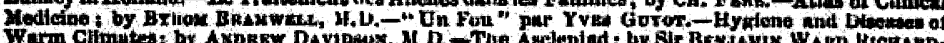

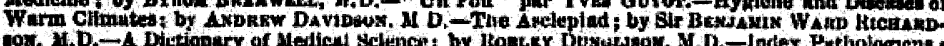

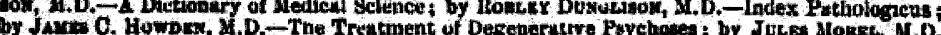

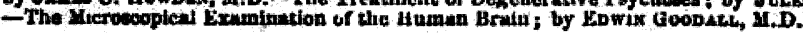

PART III.-PSYCHOLOCICAL RETROSPECT.

1. Englialih Retrospect (ArJinm Reports).

2. German Hetrospect ; by W. W. IxkLND, M.D.

\$. Puthologien Retroepect f by Epwis Goopatil, M.D.

PART IV.-NOTES AND NEWS.

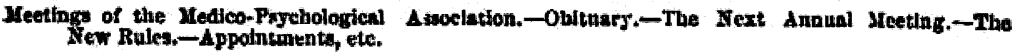




\section{JOURNAL OF MENTAL SCIENCE. JULY, 1894.}

\section{CONTENTS.}

PART I,-ORIGINAL ARTICLES.

John A. Wallis, M.D. - On the Separate Trentment of Rscent and Curable Cases of Insanity in Special Detached Hospitals. (With Plan.)

Lionel A. Weatherly, M.D.-The Trials and Troubles and Grievances of a Private Asylum Superintendent.

William W. Ireland, M.D.-On Affections of the Musical Faculty in Cerebral Diseases.

Richard Legge, M.D.-Music and the Musical Faculty in Insanity.

W. F. Menzies, M D.-The Future Supply and Status of the Nursing Staff in Asylums.

T. Algernon Chapman, M.D. - Ages and Death-rates of Lunatics in the Districts where "Accumulation" of Lunatics is most Advanced. (With Diagrams.)

John Carswell, L.R.C.P.Ed.-History of an Experiment in dealing with Reported Cases of Insanity in the Barony Parish of Glasgow.

Clinical Notes and Cases.-Trephining for Epilepsy; by T. DUNCAN GreENLEEs, M.B.Edin.--Unruptured Tubal Pregnancy, with Cystic Tumour of the Opposite Ovary; by A. C. ButLer-SMrthe, F.R.C.P.Ed.

Occasional Notes of the Quarter.-The New Rules of the Medico-Psychological Association.-Regina v. Sherrard.-The Zierenbery Case.-Sir James Stephen-Lord Hannen.-The Lewisham Workhouse Case.-The Asylum Chaplain's Column.

PART II.-REVIEWS.

La Reina Donna Juana la Loca, estudio historico; por Avtoxio RoDrtavez ViluA.-Der Verbrecher in Anthropologiseher Beziehung; von Dr. A. BAER, - Suicide and Insanity: a Physiological and Sociological Study; by S. A. K. StraHis, M.D.-Man and Woman: a Study of Human Secondary Sexual Characters; by Havelock EuLIs,-Headache and other Morbid Cephalic Sensations; by HarRY CaMrpert, M.D. -A Rejoinder to Professor Weismann; by Herbert Spencer,-An Essay Concerning Human Understanding; by JOHN LOckE; collated and annotated by Professor Fruser.-Les Grands Aliénistes Français; par le Dr. Réne SemelatgNe. - Lunatic Asylums : their Organization and Management; by Charles Mercier, M.B.

$$
\text { PART III.-PSYCHOLOGICAL RETROSPECT. }
$$

1. English Retrospect (Asylum Reports).

2. Retrospect of Criminal Anthropology; by Havelock Elis.

3. German Retrospect; by W. W. IreLinD, M.D.

$$
\text { PART IV.-NOTES AND NEWS. }
$$

Divisional Meeting of the Medico-Psychological Association,-Mariano Williams v. Beaumont and Duke: Judgment,-Obituaries.-Editorial Changes.-Appointments.-Index Medico-Psychologicus, ete.

The Editors do not hold themselves responsible for the views of Contributors whose names or initials, \&c., are given.

Vol. XL., No. CLXXI. (New Series, No. 135) will be published on the 1st of October, 1894.

GoUTu Coestres phess Lisuted, LSW rs. 